\title{
Sıvı Olarak Toprağa Uygulanan Hümik Asit Miktarlarının Kırmızı Mercimek Bitkisinde (Lens culinaris Medic.) Verim ve Bazı Verim Unsurlarına Etkisi
}

\author{
*Ayșe Gülgün ÖKTEM ${ }^{1}$, Abdullah Suat NACAR², Abdullah ÖKTEM ${ }^{1}$ \\ ${ }^{1}$ Harran Üniversitesi Ziraat Fakültesi Tarla Bitkileri Bölümü, Șanlıurfa \\ ${ }^{2}$ GAP Tarımsal Araștırma Enstitüsü Müdürlüğü, Șanlıurfa \\ *Sorumlu yazar e-posta (Corresponding author e-mail): gulgunoktem@harran.edu.tr
}

\begin{abstract}
Öz
Bu çalıșma ile farklı miktarlarda toprağa uygulanan hümik asit seviyelerinin kırmızı mercimek bitkisinde verim ve bazı verim unsurlarına olan etkisini belirlemek amaçlanmıștır. Araștırma 2009-2010 ve 2010-2011 yıllarında Harran Ovası koșullarında iki yıl süre ile yürütülmüștür. Araștırmada materyal olarak sıvı hümik asit ve bölgede yaygın bir șekilde ekimi yapılan Fırat-87 kırmızı mercimek çeșidi kullanılmıștır. Deneme tesadüf blokları deneme desenine göre dört tekrarlamalı olarak yürütülmüștür. Toprağa uygulanan hümik asit seviyeleri; kontrol, $2 \mathrm{~L} \mathrm{da}^{-1}, 4 \mathrm{~L} \mathrm{da}^{-1}, 6 \mathrm{~L} \mathrm{da}^{-1}$ ve $8 \mathrm{~L} \mathrm{da}^{-1}$ olarak belirlenmiștir. Araștırmada tane verimi, bitki boyu, ilk bakla yüksekliği, bin tane ağırlığı, hasat indeksi, bakla sayısı değerleri incelenmiștir. Tane verimi bakımından iki yılın ortalamasına göre en düșük değer kontrol parsellerinden elde edilirken, en yüksek değer $8 \mathrm{~L} \mathrm{da}^{-1}$ hümik asit uygulamasından elde edilmiștir. Bitki boyu, bakla yüksekliği, bakla sayısı bakımından en düșük değerleri kontrol parselleri vermiștir.
\end{abstract}

Anahtar Kelimeler: Harran Ovası, kırmızı mercimek, hümik asit

\section{The Effects of Different Levels of Liquid Humic Acid Application onto the Soil on Yield and Certain Some Yield Characteristics of Red Lentil (Lens culinaris Medic.)}

\section{Abstract}

This study aimed to determine the effects of humic acid levels applied to soil on different amounts of red lentil plant to yield and some yield components. Present research was conducted at Harran Plain conditions in 2009-2010 and 2010-2011 during two growing seasons. Different liquid humic acid levels were applied to CV Firat-87 red lentil variety which is grown commonly in the region. Experimental design was established as randomized block design technique with four replicates. Liquid humic acid levels were control, $2 \mathrm{~L} \mathrm{da}^{-1}$, $4 \mathrm{~L} \mathrm{da}^{-1}, 6 \mathrm{~L} \mathrm{da}^{-1}$, $8 \mathrm{~L} \mathrm{da}^{-1}$ humic acid. Plant height, first number pod height, pod number, thousand kernel number and grain yield were evaluated in the study. According to two years average, the highest grain yield value was obtained from $8 \mathrm{~L} \mathrm{da}^{-1}$ humic acid levels. Control plots gave the lowest plant height, pod height and number of pods.

Keywords: Harran Plain, red lentil, humic acid

\section{Giriș}

$\mathrm{M}$ ercimek, içerdiği yüksek protein, demir ve mineraller bakımından beslenmede, azot bağlama özelliğinden dolayı ise ekim nöbeti sisteminde önemli bitkilerden birisidir.

Mercimek Türkiye'de 2.354.743 da alanda yetiștirilmekte ve 345.000 ton üretim yapılmaktadır. Ortalama verim ise $147 \mathrm{~kg}$ $\mathrm{da}^{-1}$ 'dır. Kırmızı mercimek en fazla GAP bölgesinde yetiștirilmekte olup, bölge ve

ülke ekonomisine büyük katkı sağlamaktadır. Güneydoğu Anadolu Bölgesi'nde 2.279.114 da alanda yetiștirilmekte, 334.150 ton üretim sağlanmakta ve $150 \mathrm{~kg} \mathrm{da}^{-1}$ ortalama verim elde edilmektedir. Kırmızı mercimeğin en fazla yetiștirildiği il olan Șanlıurfa'da ise 1.059.032 da alanda mercimek tarımı yapılmakta, 96.086 ton üretim sağlanmakta olup, ortalama verim $94 \mathrm{~kg} \mathrm{da}^{-1}$ seviyelerindedir (Anonim, 2017a). 
Mercimeğin yetiștirildiği alanlar organik madde yönünden zayıf olup, üretimi kısıtlayan faktörler arasında yer almaktadır. Bitkinin toprakta iyi bir gelișim sağlayabilmesi, diğer koșulların yanında önemli derecede yetiștiği toprak ortamının fiziksel özellikleri ile ilișkilidir. Toprağın verimliliği, bünyesindeki besin maddelerinin zenginliği ile ölçülür. Besin maddelerinin zenginliğini ise, o topraktaki organik maddenin miktarı belirler.

Topraktaki organik materyalin temel maddesi ise humustur. Humus genellikle bitki kısımlarının toprak altında uzun yıllar beklemesiyle olușmakta ve ekolojik sistemde toprağın verimliliğini sürekli kılmaktadır. Günümüzde artan kimyasal gübre kullanımı humusun hızla tükenmesine neden olmuștur. Oysa ki, humus gübrelerin alınımını kolaylaștıran bir maddedir. Toprağın üst kademelerinde 10-30 $\mathrm{cm}$ aralığında bulunan ince bir tabakadır. Humus içerisindeki bileșenlerin büyük bir kısmını ise hümik asitler olușturur. Hümik asitler ise bitkinin topraktan bazı besin maddeleri, vitamin ve iz elementlerin alımını kolaylaștırmaktadır. Toprakların organik madde kapsamlarının arttırıması için birçok organik kaynak kullanılmakla birlikte, son yıllarda hümik asit toprağın organik madde kapsamının arttıılması ve bitkisel üretimde verimin yükseltilmesi için kullanılan materyallerin bașında gelmektedir.

Hümik asit ile ilgili mercimekte yapılmıș çalıșmaların yanı sıra, değișik bitkilerde yapıımıș çalıșmalar da bulunmaktadır. Günaydın (1999), yapraktan ve topraktan uygulanan hümik asitin mısırın gelișimi ile bazı besin maddeleri alımına etkisini araștırdığı çalıșmasında, topraktan yapılan uygulamada hümik asitin mısır bitkisinin kuru madde miktarı üzerine etkisini istatistiki yönden önemli bulmuștur. Sharif et al. (2004), Pakistan'da organik ve inorganik gübrelerin mısır bitkisinin verim ve verim unsurları üzerine etkilerini karșılaștırmak için yürüttükleri bir tarla denemesinde, en yüksek tane verimini, en yüksek toplam kuru madde miktarını ve en yüksek bin tane ağırlığını organik gübre ve inorganik gübreye hümik asit ilave edilmesi sonucunda elde etmișlerdir. Öktem ve ark. (2015), farklı seviyelerde yapraktan hümik asit uygulamasının mısır bitkisinin verim ve bazı verim unsurları üzerine etkisini belirlemek amacıyla yaptıkları çalıșmada, yapraktan $\% 0,7$ hümik asit uygulaması bütün özelliklerde daha iyi sonuç vermiștir. Yapraktan hümik asit uygulamalarında kontrol uygulamasına göre daha yüksek tane verimi değerleri elde etmișlerdir.

Ali-Zade and Gadzhieva (1977), nohuda uygulanan $20 \mathrm{mg} \mathrm{L}^{-1}$ düzeyindeki hümik asitin tepe ve kök gelișimi ile kuru madde kapsamını artırdığını açıklamıșlardır. Öktem ve ark. (2013a) Șanlıurfa Harran Ovası koșullarında 2010 ve 2011 yıllarında kırmızı mercimek bitkisine ekim öncesi tohuma hümik asit uygulamalarının verim ve verim unsurlarına etkisini incelemek amacıyla yürüttükleri çalıșmada ekim öncesi hümik asidi tohuma $0, \% 1,25, \% 2,5, \% 5$ ve $\% 10$ seviyelerinde uygulamıșlardır. Tohuma $\% 5$ seviyesinde hümik asit uygulamasının en yüksek tane verimini verdiğini bildirmișlerdir. Öktem ve ark. (2013b), Șanlıurfa Harran Ovası koșullarında 2010 ve 2011 yıllarında yürüttükleri çalıșmada; hümik asidi buğdayda ekim öncesi tohuma $0, \% 1,25, \% 2,5, \% 5$ ve $\% 10$ seviyelerinde uygulamıșlardır. En yüksek tane veriminin $\% 5$ ve $\% 10$ tohum uygulamalarından elde edildiğini bildirmișlerdir. Öktem ve ark. (2013 c), Șanlıurfa Harran Ovası koșullarında farklı dozlarda leonardit uygulamalarının kırmızı mercimeğin verim ve verim unsurlarına etkisini belirlemek amacıyla farklı dozlarda leonardit uygulaması yapmıșlardır. Leonardit dozlarını, kontrol, $1,5 \mathrm{~kg} \mathrm{da}^{-1}, 3 \mathrm{~kg} \mathrm{da}^{-1}, 6 \mathrm{~kg}$ $\mathrm{da}^{-1}, 12 \mathrm{~kg} \mathrm{da}^{-1}$ ve $24 \mathrm{~kg} \mathrm{da}^{-1}$ leonardit olarak belirlemișlerdir. Araștırmada tane verimi yanında bitki boyu, bakla sayısı, ilk bakla yüksekliği, bin tane ağırlığı ve hasat indeksi gibi özellikleri incelemișler, en yüksek tane verimini $3 \mathrm{~kg} \mathrm{da}^{-1}$ leonardit uygulamasından elde etmișlerdir.

Bu çalıșma ile, farklı dozlarda sıvı hümik asit uygulamalarının kırmızı mercimek bitkisinde verim ve verim unsurlarına etkisini belirlemek amaçlanmıștır.

\section{Materyal ve Yöntem}

Bu çalıșma 2009/2010 ve 2010/2011 yıllarında Șanlıurfa Harran Ovası'nda yürütülmüștür. Deneme yerine ait bazı kimyasal özellikler Çizelge 1'de, araștırmanın yürütüldüğü yıllara ait yetișme periyodu 
Çizelge 1. Araștırma alanının bazı kimyasal özellikleri

Table 1. Some chemical properties of the research area

\begin{tabular}{cccccccccc}
\hline YIl & $\begin{array}{c}\text { Der. } \\
(\mathrm{cm})\end{array}$ & $\begin{array}{c}\mathrm{EC} \\
\left.(\mathrm{d} \mathrm{Sm})^{-1}\right)\end{array}$ & $\begin{array}{c}\mathrm{CaCO}_{3} \\
(\%)\end{array}$ & $\mathrm{pH}$ & $\begin{array}{c}\mathrm{P}_{2} \mathrm{O}_{5} \\
\left(\mathrm{~kg} \mathrm{da}^{-1}\right)\end{array}$ & $\begin{array}{c}\mathrm{K}_{2} \mathrm{O} \\
\left(\mathrm{kg} \mathrm{da}^{-1}\right)\end{array}$ & $\begin{array}{c}\text { Org. } \\
\mathrm{Mad} . \\
(\%)\end{array}$ & $\begin{array}{c}\mathrm{Fe} \\
\left(\mathrm{mg} \mathrm{kg}^{-1}\right)\end{array}$ & $\begin{array}{c}\mathrm{Zn} \\
\left(\mathrm{mg}^{-1}\right)\end{array}$ \\
\hline 2010 & $0-20$ & 1.174 & 30.40 & 7.79 & 2.44 & 123.1 & 1.56 & 8.351 & 0.415 \\
2011 & $0-20$ & 1.117 & 26.90 & 7.88 & 3.19 & 97.20 & 1.13 & 5.213 & 0.461 \\
\hline
\end{tabular}

Çizelge 2. Mercimeğin büyüme periyoduna ait bazı meteorolojik parametreler Table 2. Some meteorological parameters related to the growth period of the lentil

\begin{tabular}{|c|c|c|c|c|c|c|c|c|c|c|}
\hline YII & Aylar $\rightarrow$ & 1 & 2 & 3 & 4 & 5 & 6 & 10 & 11 & 12 \\
\hline \multirow{5}{*}{$2009 / 2010$} & Maks. sıc. $\left({ }^{\circ} \mathrm{C}\right)$ & 17.8 & 21.0 & 27.1 & 30.6 & 37.2 & 42.0 & 35.2 & 29.7 & 28.1 \\
\hline & Min. sic. $\left({ }^{\circ} \mathrm{C}\right)$ & -4.0 & -2.8 & 0.9 & 4.1 & 10.2 & 16.8 & 7.1 & 3.8 & 0.0 \\
\hline & Ort. sic. $\left({ }^{\circ} \mathrm{C}\right)$ & 7.6 & 9.6 & 13.9 & 17.8 & 24.2 & 29.2 & 21.2 & 15.3 & 10.1 \\
\hline & Ort. Nispi nem (\%) & 69.4 & 68.8 & 60.3 & 49.8 & 38.7 & 36.0 & 52.8 & 35.3 & 63.1 \\
\hline & Top. yağıș (mm) & 36 & 12.6 & 23.5 & 3.6 & 5.7 & 0.6 & 9.6 & - & 26.8 \\
\hline \multirow{5}{*}{$2010 / 2011$} & Maks. sıc. $\left({ }^{\circ} \mathrm{C}\right)$ & 14.6 & 17.8 & 25.2 & 28.5 & 34.9 & 38.9 & 32.7 & 21.4 & 16 \\
\hline & Min. sic. $\left({ }^{\circ} \mathrm{C}\right)$ & 0.3 & -0.9 & 2.3 & 4.3 & 11.3 & 17.7 & 8.8 & -0.4 & 0.8 \\
\hline & Ort. sic. $\left({ }^{\circ} \mathrm{C}\right)$ & 7.3 & 7.6 & 12.3 & 15.4 & 21.3 & 28.3 & 19.3 & 9.4 & 7.4 \\
\hline & Ort. Nispi nem (\%) & 62.9 & 64.7 & 46.1 & 59.9 & 46.6 & 30.3 & 53.7 & 53.7 & 57.4 \\
\hline & Top. yağıș (mm) & 58 & 28.2 & 42 & 133.7 & 39.2 & 4.6 & 12.3 & 62.1 & 47.1 \\
\hline
\end{tabular}

1. Ocak, 2. Șubat, 3. Mart, 4. Nisan, 5. Mayıs, 6. Haziran, 10. Ekim, 11. Kasım, 12. Aralık

Kaynak: Sanlıurfa Meteoroloji İstasyonu (Anonim, 2010 ve 2011).

1. January, 2. February, 3. March, 4. April, 5. May, 6. June, 10. October, 11. November, 12. December

Source: Sanliurfa Meteorological Station (Anonymous, 2010 and 2011).

boyunca elde edilen iklim verileri ise Çizelge 2'de verilmiștir.

Araștırmanın yürütüldüğü Harran Ovası, doğu, batı ve kuzeyden çevreleyen Tektek, Fatik ve Urfa Dağlarından gelen çamur akıntılarından olușmuș, alüviyal ana materyalli, düz ve düze yakın eğimli, derin topraklardır. Tipik kırmızı profilleri killi bünyelidir. Tüm profil çok kireçlidir ve așağılara doğru artan yoğunlukta kireç ceplerini içermektedir. A, B, C horizonlu topraklar olup, $\mathrm{pH} 7.3$ ile 7.8 arasında, organik madde içeriği düșük, katyon değișim kapasitesi kil içeriğine bağlı olarak alt katmanlara doğru artmaktadır (Dinç ve ark. 1988).

Araștırmada materyal olarak; Türkiye Kömür İșletmeleri tarafından üretilen hümik asit kullanılmıștır. Kullanılan hümik asidin içeriğinde \%5 toplam organik madde, $\% 12$ toplam hümik + fulvik asit, \%3 suda çözünebilir $\mathrm{K}_{2} \mathrm{O}$ bulunmakta olup, $\mathrm{pH}$ ise 11-13 civarındadır. Bitkisel materyal olarak bölgede yaygın bir șekilde üretimi yapılan Fırat-87 kırmızı mercimek çeșidi kullanılmıștır. Fırat-87 mercimek çeșidi, 40-50 cm boyunda, yarı yatık gelișen, orta derecede dallanan bitki yapısına sahiptir. Kıșa ve kurağa dayanıklı, yatmaya orta derecede dayanıklı, orta erkenci bir çeșittir. Güneydoğu Anadolu Bölgesi'nin tüm illerinde yetiștirilebilmektedir. Bin tane ağırlığı 35-40 g'dır (Anonim, 2013b).

Deneme tesadüf blokları deneme deseninde dört tekrarlamalı olarak yürütülmüștür. Parsel ölçüleri ekimde: $2.40 \mathrm{~m} \times 6.00 \mathrm{~m}=14.40 \mathrm{~m}^{2}$, hasatta: $1.20 \mathrm{~m} \times 4.00 \mathrm{~m}=4.80 \mathrm{~m}^{2}$ olarak düzenlenmiștir.

SIVı hümik asit seviyelerini kontrol, $2 \mathrm{~kg}$ $\mathrm{da}^{-1}, 4 \mathrm{~kg} \mathrm{da}^{-1}, 6 \mathrm{~kg} \mathrm{da}^{-1}, 8 \mathrm{~kg} \mathrm{da}^{-1}$ sıvı hümik asit olușturmuștur. Ön bitki hasadından sonra kulaklı pullukla derin sürüm yapılmıș, ardından disk harrow ve tapan çekilerek deneme yeri ekime hazır hale getirilmiștir. Belirtilen dozlarda sıvı hümik asit her parsele su ile uygulanacak șekilde sulandırılarak, ekimden hemen önce toprağa pülverizatörle püskürtülmüș, 10-15 $\mathrm{cm}$ derinliğe karıștııılmıștır. Kontrol parsellerine sadece su püskürtülmüștür. Daha sonra hububat mibzeri ile sıra arası $17 \mathrm{~cm}$ olacak șekilde ve $10 \mathrm{~kg} \mathrm{da}^{-1}$ tohum düșecek șekilde parsellere ekim yapılmıștır. İlk yıl 10.01.2010 tarihinde, ikinci yıl ise 25.11.2011 tarihinde ekim gerçekleștirilmiștir. Taban gübresi olarak 20-20-0 kompoze gübre, $6 \mathrm{~kg} \mathrm{da}^{-1}$ saf $\mathrm{N}$ ve 
Çizelge 3. Bitki boyu, ilk bakla yüksekliği ve bin tane ağırlığı değerleri

Table 3. Plant height, first pod height and thousand kernel weigth values

\begin{tabular}{cccccccccc}
\hline \multirow{2}{*}{\begin{tabular}{c} 
Hümik Asit $\left(\mathrm{L} \mathrm{da}^{-1}\right)$ \\
\cline { 2 - 10 }
\end{tabular}} & \multicolumn{3}{c}{ Bitki Boyu $(\mathrm{cm})$} & \multicolumn{3}{c}{ Illk Bakla Yüksekliği } & \multicolumn{3}{c}{ Bin Tane Ağırlığı } \\
\hline 0 & 38.75 & 36.13 & 37.44 & 27.0 & 13.50 & 20.25 & 38.6 & 37.4 & 38.00 \\
2 & 42.50 & 35.80 & 39.15 & 27.3 & 15.03 & 21.17 & 37.7 & 35.6 & 36.65 \\
4 & 42.50 & 38.95 & 40.73 & 30.8 & 15.85 & 23.33 & 39.4 & 36.8 & 38.10 \\
6 & 40.50 & 36.28 & 38.39 & 29.5 & 16.45 & 22.98 & 38.6 & 36.7 & 37.65 \\
8 & 42.50 & 34.88 & 38.69 & 28.3 & 12.45 & 20.38 & 38.0 & 37.5 & 37.75 \\
Önemlilik & öd & öd & öd & öd & öd & öd & öd & öd & öd \\
\hline Öd: önemli değil & & & & & & & & &
\end{tabular}

Od: non significant

$\mathrm{P}_{2} \mathrm{O}_{5}$ gelecek șekilde ekimle birlikte gübreleme yapılmıștır. Bitkilerin hasat olgunluğuna ulaștığı dönemde, hasat biçerdöver ile yapılmıș ve parsel verimleri tartılarak kaydedilmiștir.

\section{Bulgular ve Tartıșma}

Bitki Boyu (cm): Yapılan varyans analizine göre her iki deneme yilında da bitki boyu bakımından istatistiki olarak farklılı görülmemiștir (Çizelge 3). Ancak, her iki deneme yılında da en düșük bitki boyu değeri kontrol uygulamasından elde edilmiștir. Yıllar ortalamasına göre en yüksek bitki boyu değeri $4 \mathrm{~L} \mathrm{da}^{-1}$ hümik asit uygulamasından elde edilmiștir $(40,73 \mathrm{~cm})$. Bitki boyu çevre koșullarından etkilenen bir özellik olmakla birlikte, ağırlıklı olarak bitkinin genetik yapısından etkilenmektedir. Araștırmada kullanılan Fırat-87 mercimek çeșidi genellikle 40-50 cm boylanabilen özelliğe sahiptir.

İlk Bakla Yüksekliği (cm): İlk bakla yüksekliği bakımından yıllar ortalamasına göre en yüksek bakla yüksekliği değeri $4 \mathrm{~L}$ $\mathrm{da}^{-1}$ hümik asit uygulamasından elde edilirken (23.33 cm), en düșük bakla yüksekliği ise kontrol parsellerinden elde edilmiștir (20.25 $\mathrm{cm})$. Hümik asit uygulamaları $8 \mathrm{I} \mathrm{da}^{-1}$ seviyesine kadar bir miktar artıș sağlamıștır, ancak bu artıș istatistiki olarak önemli bulunmamıștır.

Bin Tane Ağırlığı (g): Her iki deneme yılı ortalamasına göre en yüksek bin tane ağırlığı değeri $4 \mathrm{~L} \mathrm{da}^{-1}$ hümik asit uygulamasından elde edilmiștir (38.10 g). Eser (1970), ülkemizde yetiștirilen mercimeklerde orta irilikteki tohumların bin tane ağılıklarının 35.3-54.7 g arasında değiștiğini bildirmektedir. Yaptığımız araștırmada bin tane ağırlığı değerlerinin 36.65$38.10 \mathrm{~g}$ arasında değiștiği görülmektedir. Hümik asit uygulamalarının bin tane ağırlığı üzerinde istatistiki olarak etkili olmadığı saptanmıștır.

Hasat İndeksi (\%): İki yılın ortalamasına göre hasat indeksi bakımından en düșük değer $4 \mathrm{~L} \mathrm{da}^{-1}$ uygulamasından elde edilirken, en yüksek değer $4 \mathrm{~L} \mathrm{da}^{-1}$ uygulamasından elde

Çizelge 4. Hasat indeksi, bakla sayısı ve tane verimi değerleri Table 4. Harvest index, pod number and grain yield values

\begin{tabular}{cccccccccc}
\hline \multirow{2}{*}{$\begin{array}{c}\text { Hümik Asit da } \\
\left(\text { L da }^{-}\right.\end{array}$} & \multicolumn{3}{c}{ Hasat İndeksi (\%) } & \multicolumn{3}{c}{ Bakla Sayıs (adet/bitki) } & \multicolumn{3}{c}{ Tane Verimi (kg da-1) } \\
\cline { 2 - 10 } & $2009 / 10$ & $2010 / 11$ & Ort. & $2009 / 10$ & $2010 / 11$ & Ort. & $2009 / 10$ & $2010 / 11$ & Ort. \\
\hline 0 & 20.5 & 40.9 & 30.70 & $19.1 \mathrm{~b}$ & $33.9 \mathrm{~cd}$ & 26.5 & 59.0 & 207.66 & 133.3 \\
2 & 21.9 & 40.4 & 31.15 & $22.9 \mathrm{a}$ & $40.7 \mathrm{a}$ & 31.8 & 62.8 & 224.83 & 143.8 \\
4 & 20.2 & 38.5 & 29.35 & $21.0 \mathrm{ab}$ & $31.7 \mathrm{~d}$ & 26.4 & 61.4 & 237.26 & 149.3 \\
6 & 22.2 & 39.4 & 30.80 & $21.2 \mathrm{ab}$ & $35.6 \mathrm{bc}$ & 28.4 & 63.3 & 229.38 & 146.3 \\
8 & 20.7 & 40.1 & 30.40 & $23.0 \mathrm{a}$ & $38.0 \mathrm{ab}$ & 30.5 & 61.1 & 237.90 & 149.5 \\
LSD & & & & 2.54 & 2.79 & & & & \\
önemlilik & öd & öd & & $*$ & $* *$ & öd & öd & öd \\
\hline
\end{tabular}

Öd: önemli değil, *; P<0.05, **; P<0.01

$\dagger:$ Aynı harf grubuna giren ortalamalar arasında 0.05 seviyesinde LSD testine göre önemli farlılık yoktur.

Od: non significant

$t:$ There are no significant differences between the meanings in the same letter group compared to the 0.05 level LSD test 


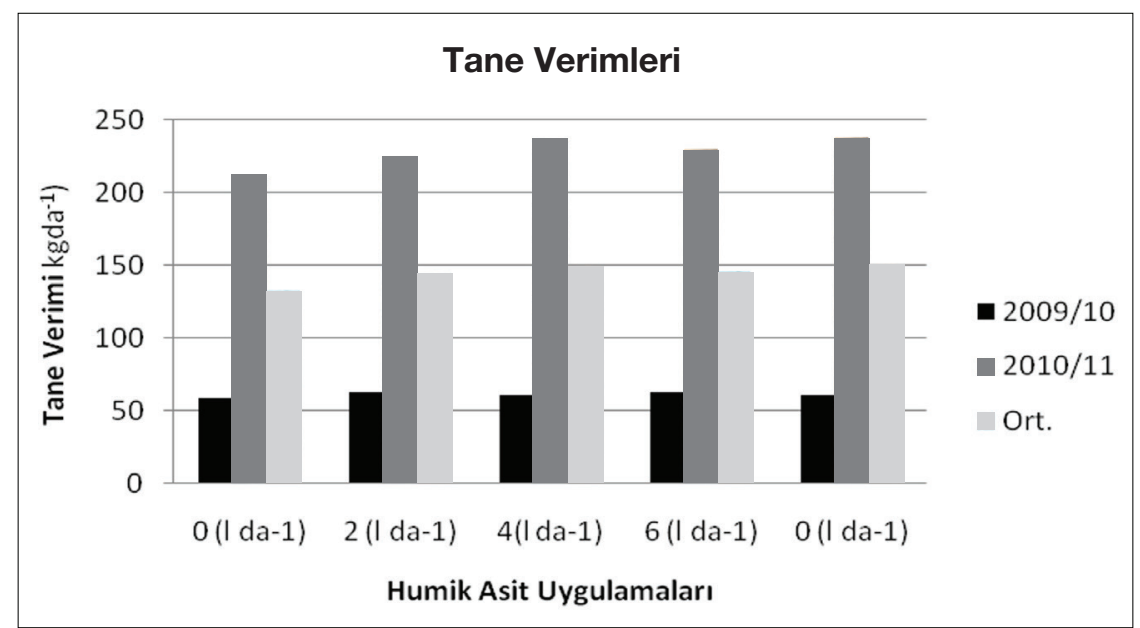

Șekil 1. Tane Verimleri

Figure 1. Grain Yields

edilmiștir. Ancak yapılan varyans analizine göre uygulamalar arasında istatistiki olarak farklılık gözlenmemiștir.

Bakla Sayısı (adet/bitki): Hümik asitin mercimekte toprağa sıvı uygulamasında bakla sayısı yönünden her ikiyılda da istatistikiyönden farklılık olușmuștur. İlk yıl en yüksek bakla sayısı değeri $8 \mathrm{~L} \mathrm{da}^{-1}$ hümik asit uygulamasından elde edilirken, ikinci yıl $2 \mathrm{~L} \mathrm{da}^{-1}$ hümik asit uygulaması en yüksek değeri vermiștir. Hümik asit uygulamalarının bakla sayısına olumlu etkide bulundukları söylenebilir. Bozoğlu ve ark. (2004), bezelyede yaptıkları çalıșmada potasyum humat uygulamasının bakla sayının arttırdığını bildirmișlerdir.

Tane Verimi (kg da $\left.{ }^{-1}\right)$ : Tane verimi sonuçları bakımından her iki deneme yılında da istatistiki olarak farklılık görülmemekle birlikte, en düșük tane verimi değerleri kontrol parsellerinden elde edilmiștir. Illk deneme yllında en yüksek tane verimi değeri $6 \mathrm{~L}$ da $^{-1}$ hümik asit uygulamasından elde edilirken, ikinci deneme yllında $8 \mathrm{I} \mathrm{da}^{-1}$ hümik asit uygulamasından elde edilmiștir. Kaptan ve Aydın (2012), tuzluluk, alkalilik, bor toksisitesi gibi toprağın fiziksel ve kimyasal yapısının bitki gelișimini sınırlandırdığı durumlarda hümik asit uygulamalarının yararlı olabileceğini belirtmișlerdir. Padem and
Öcal (1999), humik asitlerin bitki büyümesi ve gelișimi üzerinde etkili olduğunu, düșük miktarlarda uygulandığında gelișimi olumlu yönde etkilediğini; bununla beraber fazla miktarda uygulandığında gelișim üzerinde etkisiz veya olumsuz etkilere sahip olduğunu belirtmișlerdir.

Her iki deneme yllında da en düșük tane verimi değerleri kontrol parsellerinden elde edilmiștir. İlk deneme yılındaki tane verimleri, ikinci deneme yılındaki tane verimlerinden daha düșük bulunmuștur. İlk deneme yılında yașanan kuraklıktan bitkiler olumsuz etkilenmiștir. 2010/2011 deneme yilında ise ekimin zamanında yapılması, özellikle bakla bağlama ve tane dolumu dönemindeki düzenli ve yeterli yağıșlar tane verimini yükseltmiștir.

Mercimeğin bir baklagil bitkisi olması, toprağa azot ve organik madde sağlaması nedeniyle hümik asit uygulamalarından tepki alınamadığı düșünülmektedir. Her iki deneme yılında da tane verimi bakımından istatistiki olarak farklıık saptanamamıș olmasına rağmen, kontrole göre Hümik asit uygulamaları ile tane veriminde az da olsa artıș sağlanmıștır (Șekil 1). Toprağa hümik asit uygulamalarının farklı toprak tiplerinde ve farklı ekolojilerde denenmesi faydalı olacaktır.

\section{Kaynaklar}

Anonim 2013a. Türkiye İstatistik Enstitüsü Yıllığı. http://www.tuik.gov.tr

Anonim 2013b. Akçakale 2000 Buğday Çeșidi. http://www.gaptaem.gov.tr

Ali-Zade M.A., and Gadzhieva SI., 1977. Stimulation of plant growth and nucleic acid exchange by humic acid. Doklady Ac. Navk Azerbaidzhanskoi SSR 9: 34-36 
Bozoğlu H., Pekșen E. ve Gülümser A., 2004. Sıra aralığı ve potasyum humat uygulamasının bezelyenin verim ve bazı özelliklerine etkisi. Tarım Bilimleri Dergisi, 10(1): 53-58

Dinç U., Șenol S., Sayın M., Kapur S., Güzel N., Derici R., Yeșilsoy M.Ș., Yeğengil I., Sarı M., Kaya Z., Aydın M., Kettaș F., Berkman A., Çolak A.K., Yılmaz K., Tunçgögüs B., Çavușgil, V., Özbek H., Gülüt K.Y., Karaman C., Dinç O., Öztürk N., Kara E.E., 1988. Güneydoğu Anadolu Bölgesi Toprakları (GAT), I. Harran Ovası TÜBiTAK Tarım Ormancılık Araștırma Grubu Güdümlü Araștırma Projesi Kesin Raporu. TOAG - 534, Adana

Eser D., 1970. Türkiye'de Yetiștirilen Mercimek Çeșitlerinin Önemli Morfolojik Karakterleri Üzerine Araștırmalar. Ankara Üniv. Ziraat Fak. Yayınları :383, Ankara

Günaydın M., 1999. Yapraktan ve topraktan uygulanan hümik asidin domates ve mısırın gelișimi ile bazı besin maddeleri alımına etkisi. Ankara Üniversitesi Fen Bilimleri Enstitüsü Toprak Bölümü Yüksek Lisans Tezi. 109s

Kaptan M.A. ve Aydın M., 2012. Hümik asidin pamuk (Gossypium hirsutum L.) gelișimi ve kalite özellikleri üzerine etkileri. Sakarya Üniversitesi, Fen Edebiyat Dergisi, 2012-1, s.291-299

Öktem A.G., Nacar A.S ve Șakak A., 2013a. Hümik asidin kırmızı mercimekte (Lens Culinaris Medic.) tohuma uygulamasının verim ve verim unsurlarına etkisi. 6. Ulusal Bit. Bes. ve Gübre Kon. 3-7 Haziran 2013, Nevșehir, s.508-510
Öktem A.G., Nacar A.S., Öktem A. ve Șakak A., 2013b. Effect of seed application of humic acid to yield and yield characteristics of wheat (Triticum durum). 1. Orta Asya Modern Tar. Tek. ve Bit. Besleme Kongresi 01-03 Ekim, Kırgızistan, s.479-486

Öktem A.G., Nacar A.S., Öktem A. ve Șakak A., 2013c. Harran Ovası koșullarında farklı dozlarda leonardit uygulamasının kırmızı mercimekte (Lens Culunaris L.) verim ve verim unsurları üzerine etkisi. 10. Tarla Bit. 10-13 Eylül 2013 Konya

Öktem A., Öktem A.G. ve Çelikli E., 2015. Yapraktan farklı seviyelerde hümik asit uygulamasının mısır bitkisinin (zea mays I. indentata) verim ve bazı verim unsurlarına etkisi. 11. Tarla Bitkileri Kongresi Bildiri Özetleri 7-10 Eylül, Çanakkale, s. 114

Padem H., Öcal A. ve Alan R., 1999. Effect of humic acid added to foliar fertilizer on quality and nutrient content of eggplant and pepper seedlings. Acta Horticulture (ISHS) 491: 241246

Sharif M., Khattak R.A., and Sarir M.S., 2002. Effect of different levels of lignitic coal derived humic acid on growth of maize plants. Communications in Soil Science and Plant Analysis, 33: 35673580. doi: 10.1081/CSS-120015906 